\title{
PENGARUH FILTER DAN CYCLONE PADA REAKTOR GASIFIKASI TIPE UPDRAFT TERHADAP HASIL PEMBAKARAN SYN-GAS
}

\author{
Kemas Ridhuan ${ }^{1, \mathrm{a}}{ }^{\star}$, Yudistira. ${ }^{2, \mathrm{~b}}$ \\ 1,2, Jurusan Teknik Mesin, Fakultas Teknik, Universitas Muhammadiyah Metro \\ Jl. Ki Hajar Dewantara 15 A Kota Metro, Lampung \\ e-mail ; kmsridhuan@yahoo.co.id a, yudistira123@yahoo.com b
}

\begin{abstract}
Abstrak
Salah satu produk gas dari proses gasifikasi yaitu kandungan tar dari proses pirolisis yang tidak terdegradasi thermal dengan baik, untuk encapai efisiensi penggunaan alat maka proses gasifikasi harus melalui penyaringan dengan menggunakan filter dan pemurnian gas dengan menggunakan siklon. Pada tahap ini sangat penting dikarenakan peningkatan densitas energi produser gas melalui proses penyaringan dan pemurnian syn-gas yang terbawa dari produser gas sehingga memperlama produksi syn-gas atau pembakaran syn-gas. Tujuan penelitian ini adalah untuk mengetahui pengaruh penggunaan siklon dan filter terhadap pembakaran syn-gas pada burner, lama waktu gas produktif dan berapa banyak tar yang dapat dipisahkan oleh siklon dan filter pada proses gasifikasi tipe updraft. Metode penelitian ini dengan proses gasifikasi menggunakan reaktor tipe updraft, blower dengan daya 150 watt, bahan bakar kulit buah kelapa muda. filter dengan padatan sabut kelapa. Pengujian dengan memvariasikan penggunaan siklon dan siklon, yang dilakukan di laboratorium Teknik Mesin U.M. Metro. Hasil pengujian tanpa menggunakan siklon, dan filter menyebabkan nyala api pada burner terjadi semburan tar bersamaan dengan nyala api yang bercampur asap dengan suhu api sebesar $311^{\circ} \mathrm{C}$ dan warna api merah, setelah penambahan siklon dan filter nyala api terlihat bersih dan tidak terjadi penyemburan tar diburner serta suhu api mencapai $375^{\circ} \mathrm{C}$ dengan warna api orange kemerahan. Lama syn-gas yang keluar 2 menit setelah ditambahkan siklon dan filter lama nyala api bertambah 5 menit menjadi 7 menit. Pemurnian syn-gas berdampak pada kualitas api yang semakin membaik. Tar yang dapat dipisahkan oleh burner 490 gram, setelah penggunaan siklon dan filter, siklon mampu memisahkan tar sebanyak 320 gram, dan filter mampu memisahkan tar sebanyak 30 gram dan pada burner 70 gram.
\end{abstract}

Kata Kunci : Biomassa, Filter, Gasifikasi, Pembakaran, Siklon, Syn gas, Updraft.

\section{Pendahuluan}

Gasifikasi merupakan suatu cara memproduksi gas melalui pembakaran parsial bahan bakar biomassa padat, dimana prosesnya berlangsung pada temperatur berkisar 200 s.d. $600^{\circ} \mathrm{C}$ seperti yang dilakukan oleh Arisanty yang menggunakan biomassa kulit biji kopi [1]. Produk gas hasil gasifikasi merupakan gas mampu bakar seperti karbon monoksida (CO), Hidrogen $\left(\mathrm{H}_{2}\right)$, gas metan, pengotor inorganik seperti $\mathrm{NH}_{3}$ dan $\mathrm{HCN}$, kandungan $\mathrm{H}_{2} \mathrm{~S}$, debu halus, dan pengotor organik seperti tar. Produk gas dari proses gasifikasi terdapat kandungan tar yang tidak terdegradasi thermal dengan baik sebelum keluar dari reaktor. Jika gas dibakar diburner untuk aplikasi thermal tidak terlalu menimbulkan masalah namun dalam pengopersianya pada jangka panjang kandungan tar yang tidak dipisahkan dari gas pembakaran akan berdampak buruk pada komponen alat karena tar tersebut bersifat korosif dan mampu menyumbat pipa pengumpan gas ke burner, yang mengakibatkan penurunan efisiensi pada alat. Bila digunakan dalam pengaplikasian thermal, efisiensi penggunaan alat sangat penting maksimum 
kadar tar dalam gas $100 \mathrm{mg} / \mathrm{Nm}^{3}$, untuk mencapai parameter tersebut produser gas wajib melalui pengkondisian seperti penyaringan dengan menggunakan filter dan pemurnian gas yang masih bercampur tar dengan menggunakan siklon setelah proses pembakaran yang terjadi didalam reaktor. Pada tahap ini sangat penting dikarenakan peningkatan densitas energi produser gas melalui proses penyaringan dan pemurnian syn-gas yang terbawa dari produser gas sehingga memperlama produksi syn-gas atau pembakaran syngas.

Banyaknya tar pada proses gasifikasi tipe updraft dapat menyebabkan masalah pada komponen gasifikasi karena dalam kandungan tar terdapat zat korosif yang dapat merusak komponen, dalam hal ini dibutuhkan pemurnian pada proses gasifikasi.

Pemurnian merupakan pemisahan partikel solid menggunakan siklon, sedangkan penyaringan pemisahan gas yang masih bercampur partikel abu dan sisa pembakaran yang terbawa oleh gas dengan menggunakan filter, kedua bagian tersebut tentunya sangat berpengaruh terhadap kualitas pembakaran syngas, sehingga proses pembakaran akan menghasilkan gas (syn-gas) yang bersih.

\section{Kajian Pustaka}

\section{a. Pembakaran}

Pembakaran adalah suatu runutan reaksi kimia antara suatu bahan bakar dan suatu oksidan, disertai dengan produksi panas yang kadang disertai cahaya dalam bentuk pendar atau api. Pembakaran dapat didefinisikan sebagai proses atau reaksi oksidasi yang sangat cepat antara bahan bakar (fuel) dan oksidator dengan menimbulkan panas atau nyala : Bahan bakar padat + O2 Gas buang + abu - $\Delta \mathrm{H}$. Nonkarbonisasi merupakan proses pembakaran sempurnah karena terjadi dengan pemberian udara atau adanya udara yang masuk, pembakaran metana merupaka reaksi pembakaran sempurna, karena menghasilkan karbon dioksida dan air.

\section{b. Gasifikasi}

Gasifikasi merupakan metode mengkonversi secara termokimia bahan bakar padat menjadi bahan bakar gas (syngas) dalam wadah gasifier dengan menyuplai agen gasifikasi seperti uap panas, udara dan lainnya. Metode gasifikasi dinilai lebih menguntungkan dan gas pembakaran lebih bersih dibanding pembakaran langsung. Namun demikian, tekonologi gasifikasi masih perlu dikembangkan mengingat masih rendahnya efisiensi gasifikasi. Hal ini karena karakteristik biomassa khususnya kulit buah kelapa muda memiliki kadar air yang tinggi. Alat gasifikasi yang digunakan adalah updraft circulating fluidized bed gasifier. Pada temperatur awal udara yang bervariasi yaitu $300^{\circ} \mathrm{C}$ hingga $400^{\circ} \mathrm{C}$, semakin tinggi temperatur awal udara gasifikasi, semakin meningkat efisiensi gasifikasi dan efisiensi karbon. Berdasarkan Najib, bahwa komposisi syngas 39,273\% dari volume total [2]. Dan efisiensi gasifikasi terbaik terjadi pada AFR 1,17 untuk ukuran tempurung kelapa $(0,8-12,6) \mathrm{cm}^{2}$ sebesar 52,030\% .

Gasifikasi terdiri dari empat tahapan terpisah: pengeringan, pirolisis, oksidasi/pembakaran dan reduksi. Keempat tahapan ini terjadi secara alamiah dalam proses pembakaran. Dalam gasifikasi keempat tahapan ini dilalui secara terpisah sedemikian hingga dapat menginterupsi "api" dan mempertahankan gas mudah terbakar tersebut dalam bentuk gas serta mengalirkan produk gasnya ketempat lain. Salah satu cara untuk mengetahui proses yang berlangsung pada gasifier jenis ini adalah dengan mengetahui rentang temperatur masingmasing proses.

\section{c. Updraft Gasifier}

Pada tipe updraft Karakteristik gas tidak jauh berbeda dibandingkan dengan downdraft. Akan tetapi, mengingat gas keluaran reaktor updraft melalui zona 
pengeringan biomassa, gas keluaran updraft gasifier memiliki kandungan uap air lebih tinggi dibandingkan dengan downdraft gasifier. Selain itu, updraft gasifier memiliki kandungan tar yang jauh lebih tinggi dibandingkan dengan downdraft gasifier sebesar $50 \mathrm{~g} / \mathrm{Nm}^{3}$. Tar dapat terengkah pada semua temperatur, operasi yang dipilih (lebih tinggi dari $500^{\circ} \mathrm{C}$ ). Walaupun tar dapat terengkah pada temperatur tersebut, pembentukan karbon menjadi masalah serius. Pada temperatur sekitar $500-650^{\circ} \mathrm{C}$, masih terbentuk banyak deposit karbon, walaupun rasio steam/tar sudah mencapai 20. Menurut Iskandar kandungan tar yang tinggi menyebabkan nilai kalor gas produser updraft gasifier menjadi lebih tinggi karena tar yang terkandung terengkah menjadi gas $\mathrm{CO}$ dan $\mathrm{H}_{2}$ [3].

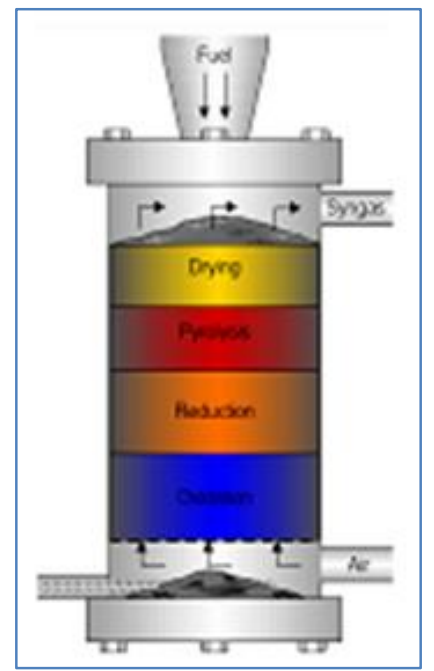

Gambar 1. Updraft gasifier

\section{d. Syn-gas (Synthetic Gas)}

Salah satu jenis sumber daya alam yang potensial mengganti dan atau mensubtitusi pemakaian gas alam adalah Synthetic Gas (Syn-gas) yang dapat diperoleh dari proses gasifikasi biomassa yang sumber dayanya masih melimpah.

Syn-gas merupakan gas campuran yang komponen utamanya adalah gas karbon monoksida $(\mathrm{CO})$ dan hidrogen $\left(\mathrm{H}_{2}\right)$ yang dapat digunakan sebagai bahan bakar dan juga dapat digunakan sebagai bahan baku dalam proses pembuatan zat kimia baru seperti metana, amonia, dan urea.
Produksi syn-gas melalui gasifikasi biomassa kualitas rendah yang jumlahnya di Indonesia mencapai $70 \%$ akan mampu memperkecil ketergantungan terhadap penggunaan sumber energi fosil [4].

\section{e. Tabung Reaktor}

Tabung reaktor adalah unit pengkonversi bahan umpan biomassa menjadi gas mampu bakar. Reaktor umum dikenal berbentuk silinder, terbuat dari bahan baja. Tabung reaktor berfungsi untuk membakar bahan bakar serbuk kayu dan menghasilkan gas karbon monoksida $(\mathrm{CO})$, hidrogen $\left(\mathrm{H}_{2}\right)$, dan metana $\left(\mathrm{CH}_{4}\right)$ yang mudah terbakar. Gas-gas lain, seperti karbon dioksida $\left(\mathrm{CO}_{2}\right)$ dan uap air $\left(\mathrm{H}_{2} \mathrm{O}\right)$ yang tidak mudah terbakar, juga dihasilkan selama proses perubahan bahan bakar serbuk kayu menjadi gas-gas yang mudah terbakar dengan menggunakan jumlah udara terbatas selama proses pembakaran [5].

\section{f. Siklon (Cyclone)}

Siklon adalah suatu metoda pembuangan partikel-partikel dari aliran udara atau gas, tanpa menggunakan penyaring, melalui pemisahan pusaran. Gravitasi dan pengaruh putaran digunakan untuk memisahkan campuran fluida dan padatan. Suatu aliran udara kecepatan putar tinggi yang terbentuk dalam suatu wadah silinder atau kerucut dinamakan sebuah siklon. Aliran-aliran udara pola spiral, simulasi pada bagian atas (sisi akhir) dari siklon dan berakhir pada bagian bawah (batas) akhir sebelum keluar siklon dalam aliran lurus sampai pusat siklon dan keluar di atas. Partikel-partikel yang lebih besar (tebal) dalam putaran aliran udara lebih lamban mengalir melengkung sulit dari aliran udara dan mencapai dinding luar, jatuh kemudian ke bagian bawah siklon yang mana partikel ini dapat terbuang [6]. 


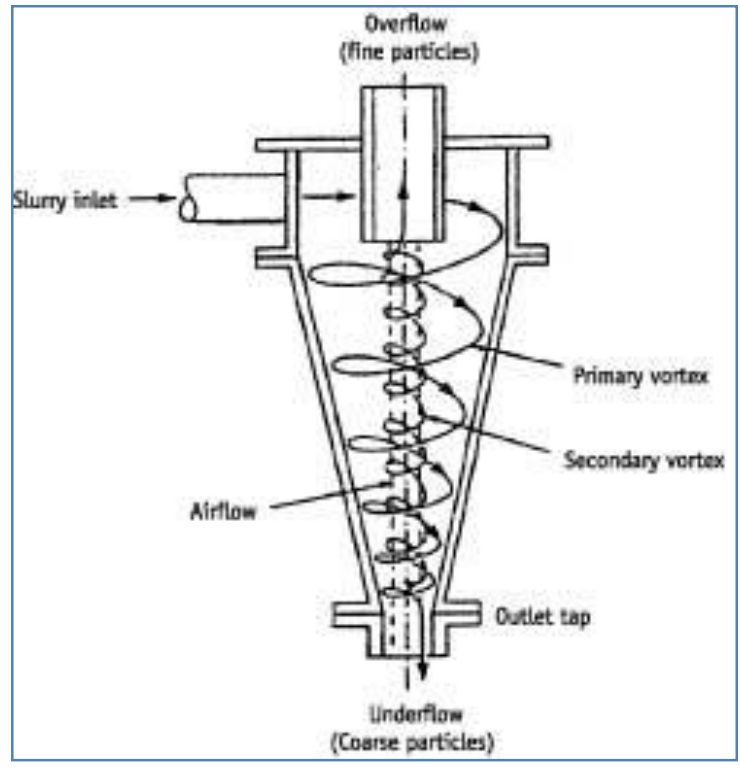

Gambar 2. Siklon (Cyclone)

\section{g. Filter}

Filter merupakan bahan berpori yang memungkinkan gas untuk menembus namun mencegah berlalunya partikel. Filter ini secara efektif menghilangkan partikel berdiameter dalam kisaran 0,5$100 \mu \mathrm{m}$ yang terdapat pada aliran gas. Filter dapat dirancang untuk menghapus hampir semua ukuran partikel, termasuk menjangkau ukuran sub-mikron, tetapi perbedaan tekanan di filter akan meningkat sejalan dengan pengecilan ukuran poripori. Akibatnya, ada kendala teknis dan ekonomis pada pemisahan partikel berukuran sekitar $0,5 \mathrm{~J} . t \mathrm{~m}$, terutama jika volume gas yang harus ditangani berjumlah besar. filter secara berkala dibersihkan dengan cara mengalirkan gas pada arah yang berlawanan dari proses filtrasi.Untuk mengurangi beban partikel secara keseluruhan, filter ini biasanya ditempatkan setelah cyclone. Beberapa contoh Filter yang digunakan dalam proses gasifikasi adalah Rigid barrier filters, Bag filters, dan Packed-bed filters.

\section{h. Biomassa}

Biomassa dapat diubah menjadi energi alternatif dengan tiga proses utama yaitu pembakaran langsung, konversi secara termokimia dan proses biologi. Konversi secara termokimia terdiri dari pirolisis, gasifikasi dan pencairan (liquefaction). Biomassa sebagian besar terdiri dari selulosa, hemiselulosa, dan lignin, dengan persentase selulosa 40$45 \%$, lignin $25-35 \%$ dan $17-25 \%$, hemiselulosa $20 \%$ dan $17-25 \%$. Pembakaran pada biomassa dapat mencapai suhu yang cukup tinggi dengan waktu yang cukup singkat.

i. Kelapa Muda

Dianggap tidak bernilai ekonomi dalam kebiasaan masyarakat, dilain pihak limbah buah kelapa itu sesungguhnya berpotensi besar menjadi dollar. Kebanyakan orang, bila melihat sabut kelapa dan ditantang untuk memanfaatkannya pasti menyebut keset, yang cuma patut dijual di pasar tradisional dengan harga yang sangat rendah. Padahal, sekarang, sabut kelapa punya peluang yang lebih bergengsi daripada sekadar keset. Dari segi penggunaan energi, biomassa berligno selulosa yang terutama mengandung selulosa dan lignin seperti pohon berada dalam jumlah yang banyak dan mempunyai potensi yang tinggi, di dalam sabut kelapa terdapat beberapa komponen dasar yang memenuhi syarat.

j. Nyala api pembakaran

Dari proses pembakaran tentunya akan menghasilkan nyala api yang berbeda tergantung proses pembakaran itu sendiri. Beberapa pembagian jenis nyala api berdasarkan warnanya :

a. Api merah yaitu api berwarna merah/kuning ini biasanya bersuhu dibawah $1000^{\circ} \mathrm{C}$, api jenis ini termasuk api yang "kurang panas"

b. Api biru yaitu api berwarna biru sering kita lihat di kompor gas. Rata-rata suhu api yang berwarna biru kurang dari $2000^{\circ} \mathrm{C}$,

c. Api putih Ini merupakan api paling panas yang ada dibumi, warna putih dari api dikarenakan suhunya melebihi 2000 derajat celcius. 


\section{Metode Penelitian}

Penelitian ini dilakukan di laboratorium Teknik Mesin UM Metro. Yang diawali dengan perancangan bentuk dan ukuran reaktor gasifikasi. Kemudian dilanjutkan dengan pembuatannya, setelah itu baru dilakukan pengujiannya. Pada pengujian divariasikan penggunaan beberapa komponen seperti pertama menggunakan reaktor, blower dan burner. Kedua menggunakan reaktor, siklon, blower dan burner. Ketiga menggunakan reaktor, filter, blower dan burner dan keempat menggunakan reaktor, siklon, filter blower dan burner. Bahan baku biomassa yang digunakan yaitu kulit kelapa muda yang telah dikeringkan

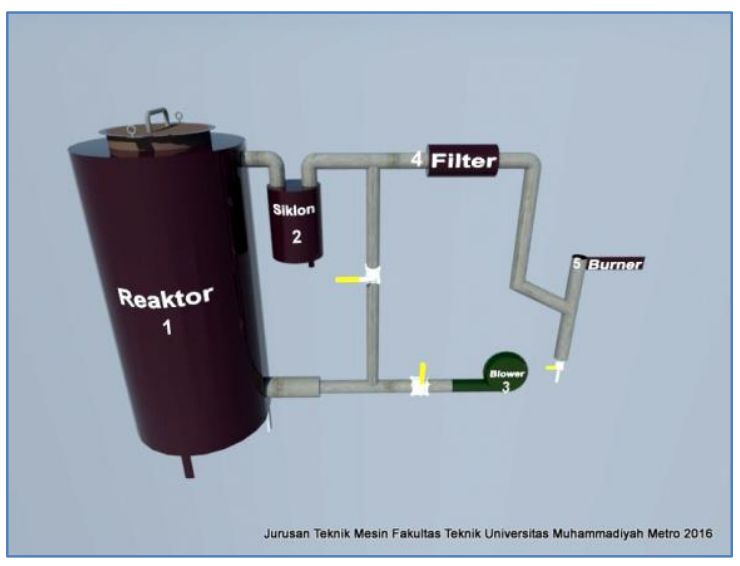

Gambar 3. Burner

Komponen yang digunakan :

1. Reaktor yaitu di bentuk dari plat menjadi silinder dengan tinggi $72 \mathrm{~cm}$ dan berdiameter $38 \mathrm{~cm}$.

2. Siklon yang berbentuk silinder dengan tinggi $20 \mathrm{~cm}$ dan berdiameter $14 \mathrm{~cm}$, pada bagian dalam silinder dipasang pipa untuk mengalirkan udara dan memisahkan syn-gas dari tar setelah proses gasifikasi.

3. Filter berbentuk silinder yang dibentuk dengan panjang $30 \mathrm{~cm}$ dan berdiameter $10 \mathrm{~cm}$, pada bagian dalam filter diberi padatan sabut kelapa sebagai penyaring syn-gas dari tar dan abu setelah proses gasifikasi.

4. Rangkaian Pipa menggunakan diameter 2,54 $\mathrm{cm}$ sebagai saluran udara ke reaktor dan keluaran syn-gas dari reaktor ke burner

5. Blower yang berfungsi untuk mendorong laju aliran gas pembakaran menuju barner dengan daya $150 \mathrm{w}$.

6. Lubang pembuangan abu berdiamete $14 \mathrm{~cm}$.

Proses Pengujian

1. Siapkan peralatan dan bahan yang dugunakan.

2. Masukkan biomassa ke dalam reaktor bagian melalui bagian atas sedikit demi sedikit untuk memudahkan penyalaan awal.

3. Lakukan penyalaan pada bahan biomassa menggunakan kertas atau minyak tanah sebagai pemantik api pada penyalaan awal.

4. Setelah beberapa menit hidupkan blower sebagai pemasok udara pada reaktor, temperatur reaktor mulai dicatat sejak blower dinyalakan setiap 3 menit.

5. Tunggu sebentar hingga mencapai temperatur rata-rata pada proses gasifikasi, kemudian syn-gas yang keluar melalui pipa keluaran dipantik hingga menyalakan api yang stabil.

\section{Hasil Dan Pembahasan}

a. Hasil Pengujian

Telah dilakukan pengujian dari rangkaian reaktor gasifikasi ini, dengan bahan baku kulit kelapa muda sebanyak 6 $\mathrm{kg}$ pada setiap pengujian, serta filter menggunakan padatan serabut kelapa 70 gram, dengan memvariasikan rangkaian pada setiap pengujian yaitu :

$\mathrm{R}_{1}=$ rangkaian dengan (reaktor \& burner),

$\mathrm{R}_{2}=$ (reaktor, siklon, dan burner),

$\mathrm{R}_{3}=$ (reaktor, filter, dan burner), dan

$\mathrm{R}_{4}=$ (reaktor, siklon, filter, dan burner).

Pengambilan data dilakukan sebanyak tiga kali pengulangan pada proses pengujian untuk mendapatkan data yang lebih akurat. Pengukuran atau pencatatan data suhu diambil setiap tiga menit sekali. Adapun datanya sebagai berikut : 
Tabel 1. Data temperatur dan lama produksi syn-gas rata-rata

\begin{tabular}{|c|c|c|c|c|c|c|}
\hline Rangkaian & $\begin{array}{c}\text { Menit } \\
\text { ke }\end{array}$ & $\begin{array}{c}\mathrm{T}_{1} \\
\text { Ruang } \\
\text { Bakar } \\
\left({ }^{\circ} \mathrm{C}\right)\end{array}$ & $\begin{array}{c}\mathrm{T}_{2} \\
\text { Reaktor } \\
\left({ }^{\circ} \mathrm{C}\right)\end{array}$ & $\begin{array}{c}\mathrm{T}_{3} \\
\text { Siklon } \\
\left({ }^{\circ} \mathrm{C}\right)\end{array}$ & $\begin{array}{c}\mathrm{T}_{4} \\
\text { Filter } \\
\left({ }^{\circ} \mathrm{C}\right)\end{array}$ & $\begin{array}{c}\mathrm{T}_{5} \\
\text { api } \\
\text { diBurner } \\
\left({ }^{\circ} \mathrm{C}\right)\end{array}$ \\
\hline \multirow[t]{2}{*}{$\mathrm{R}_{1}$} & 1 & 95 & 135 & - & - & 298 \\
\hline & 2 & 103 & 132 & - & - & 311 \\
\hline \multirow{4}{*}{$\mathrm{R}_{2}$} & 1 & 75 & 125 & 55 & - & 301 \\
\hline & 2 & 90 & 141 & 70 & - & 300 \\
\hline & 3 & 96 & 148 & 76 & - & 299 \\
\hline & 4 & 98 & 150 & 84 & - & 320 \\
\hline \multirow{5}{*}{$\mathrm{R}_{3}$} & 1 & 92 & 88 & - & 62 & 310 \\
\hline & 2 & 99 & 97 & - & 70 & 308 \\
\hline & 3 & 114 & 113 & - & 77 & 305 \\
\hline & 4 & 119 & 117 & - & 83 & 313 \\
\hline & 5 & 116 & 126 & - & 90 & 309 \\
\hline \multirow{7}{*}{$\mathrm{R}_{4}$} & 1 & 64 & 101 & 51 & 50 & 369 \\
\hline & 2 & 74 & 111 & 45 & 51 & 367 \\
\hline & 3 & 83 & 119 & 54 & 60 & 374 \\
\hline & 4 & 91 & 127 & 62 & 68 & 370 \\
\hline & 5 & 98 & 134 & 69 & 75 & 363 \\
\hline & 6 & 114 & 140 & 74 & 81 & 369 \\
\hline & 7 & 120 & 145 & 79 & 86 & 375 \\
\hline
\end{tabular}

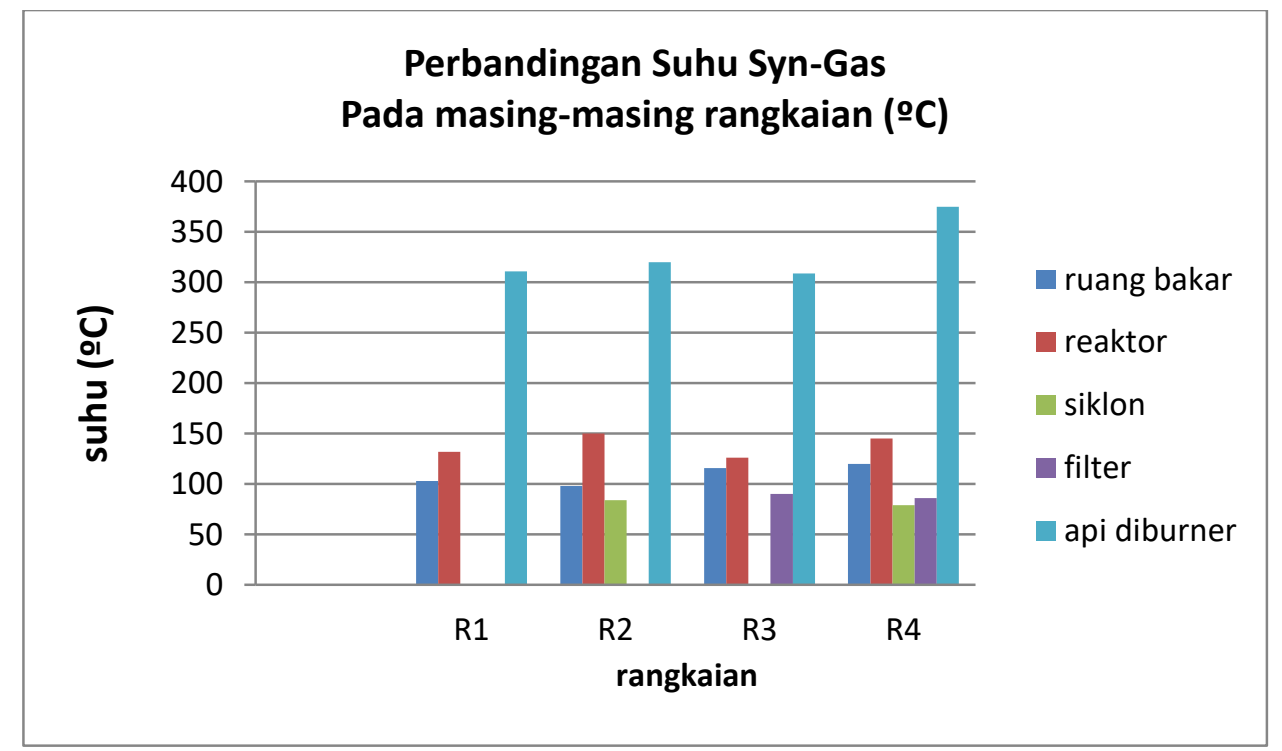

Gambar 4. Perbandingan Suhu Syn-Gas pada masing-masing rangkaian

Pada tabel 1. terlihat bahwa pada baris $\mathrm{R}_{1}$ terlihat kolom $\mathrm{T}_{3}$ dan $\mathrm{T}_{4}$ tidak ada nilai karena alat siklon dan filter tidak dipakai. Begitu pula pada baris $\mathrm{R}_{2}$ tidak menggunakan filter dan pada $\mathrm{R}_{3}$ tidak menggunakan siklon. Tetapi untuk $\mathrm{R}_{4}$ semua alat dipakai.
Pada gambar 5. pada $\mathrm{R}_{1}$ suhu pada komponen tanpa siklon dan filter terlihat tinggi dikarenakan tanpa pemurnian setelah reaktor dan suhu api di burner cenderung rendah karena masih bercampur asap dan tar yang dihasilkan oleh reaktor setelah proses pembakaran biomassa. 
Padar $\mathrm{R}_{2}$ pengujian menggunakan siklon dan tidak menggunakan filter, pada saat setelah syn-gas melewati siklon suhu sedikit menurun karena terjadi pemurnian sekaligus penurunan suhu didalam siklon, namun api diburner masih bercampur asap yang dapat menyebabkan pengembunan sehingga menghasilkan tar.

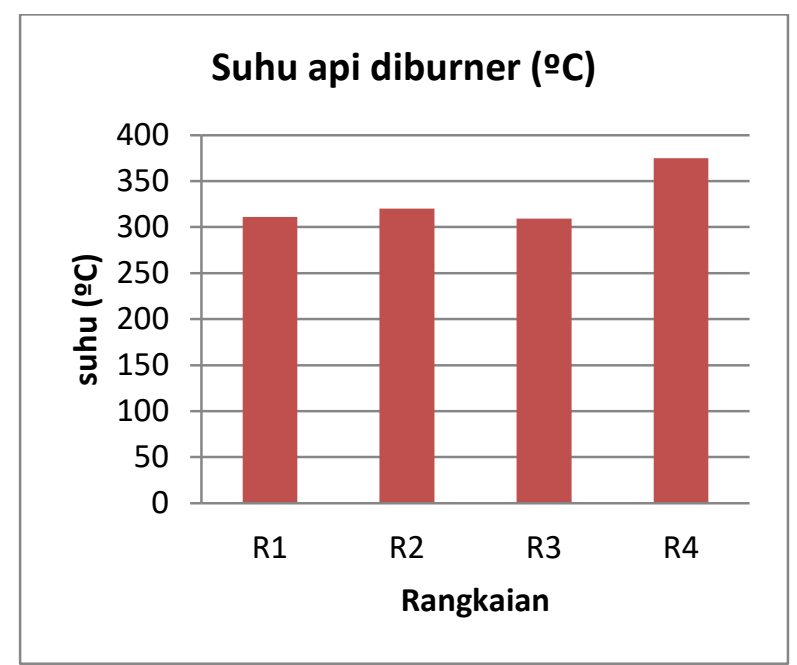

Gambar 5. Suhu api diburner masingmasing rangkaian

Kemudian pada $\mathrm{R}_{3}$ terlihat suhu didalam siklon terjadi penurunan, nyala api diburner tidak jauh berbeda dengan $\mathrm{R}_{2}$ namun lama produksi syn-gas cenderung sedikit lebih lama. Selanjutnya pada $\mathrm{R}_{4}$ terlihat penggunaan siklon dan filter berpengaruh pada suhu komponen dan lama gas produktif yang dihasilkan. Begitupun suhu nyala api diburner. Pada pengujian R4 dianggap telah mendapatkan hasil yang maksimal dibandingkan dengan rangkaian lainnya. Data perbandingan suhu api diburner pada masing-masing rangkaian seperti pada gambar 5 . b. Nyala Api di Burner pada MasingMasing Rangkaian

Nyala api yang berbeda dari masing-masing rangkaian seperti pada gambar 6. Pengujian $\mathrm{R}_{1}$ terlihat nyala api kecil dengan suhu $311^{\circ} \mathrm{C}$ dan masih bercampur asap, pada saat pengujian terlihat semburan tar dari burner, karena $\mathrm{R}_{1}$ tidak menggunakan siklon dan filter tar hanya tertampung pada burner dan berpengaruh pada syn-gas yang dihasilkan, begitupun lama nyala api di burner mencapai 2 menit.

Pada $\mathrm{R}_{2}$ menggunakan siklon dan tidak menggunkan filter, api terlihat sedikit lebih besar dibandingkan dengan nyala api $\mathrm{R}_{1}$, suhu nyala api pada $\mathrm{R}_{2}$ mencapai 320 ${ }^{\circ} \mathrm{C}$ dan lama nyala api diburner mencapai \pm 3 menit, penggunaan siklon mampu memisahkan syn-gas dari partikel solid seperti tar dan abu yang dapat menyumbat pipa syn-gas.

Dan pada $\mathrm{R}_{3}$ tidak jauh berbeda dengan $\mathrm{R}_{2}$ namun suhu api sedikit lebih rendah yaitu $309^{\circ} \mathrm{C}$, lama nyala api diburner mencapai 5 menit, penggunaan filter mampu membersihkan syn-gas dari tar dan abu, namun kinerja filter tidak mampu lama dikarenakan banyaknya tar yang tertampung di filter langsung menuju ke filter sehingga lebih cepat mengganti serabut kelapa yang digunakan sebagai filter.

Kemudian pada $\mathrm{R}_{4}$ api terlihat besar dan tidak bercampur asap, suhu nyala api mencapai suhu tertinggi dari masing-masing rangkaian yaitu $375{ }^{\circ} \mathrm{C}$ begitupun lama nyala api di burner mencapai 7 menit. 


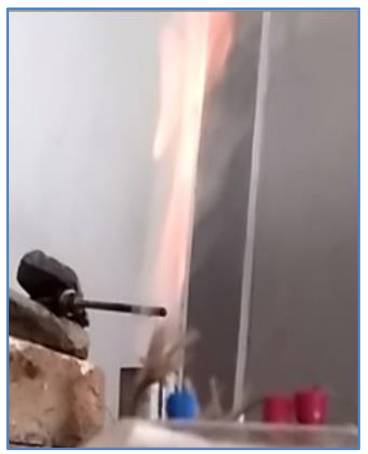

R1

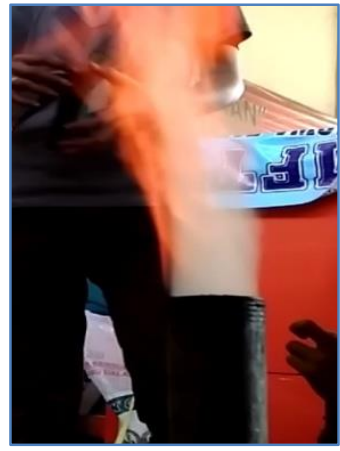

R2

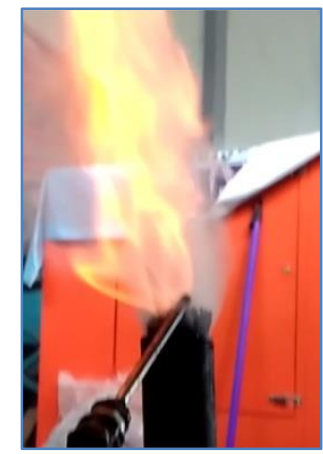

R3

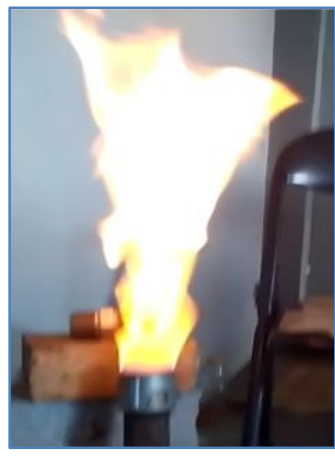

$\mathrm{R} 4$

Gambar 6. Nyala api pembakaran pada R1, R2, R3 dan R4

c. Waktu Produksi Syn-Gas Di burner

Dari hasil pengujian masingmasing rangkaian pada rangkaian 4 menunjukan hasil yang dianggap akurat, lama produksi syn-gas atau gas yang bisa dibakar mencapai 7 menit, berikut lama produksi syn-gas masing-masing rangkaian digambarkan dalam diagram batang

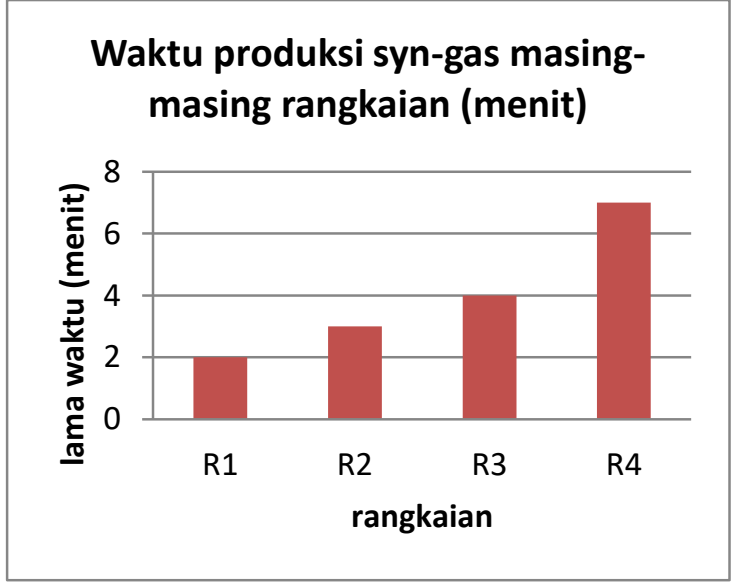

Gambar 7. Waktu produksi syn-gas masing-masing rangkaian

\section{d. Sisa Arang Setelah Pengujian Dari Keempat Rangkaian}

Data sisa arang setelah pengujian dari keempat rangkaian dengan berat biomassa masing-masing rangkaian sebelum digunakan $6 \mathrm{~kg}$ seperti gterlihat pada tabel 2. dan gambar 7 .

\section{e. Tar Yang Dapat Dipisahkan Pada Siklon, Filter, dan Burner}

Pada pengambilan data banyaknya tar yang dapat dipisahkan oleh filter dengan padatan serabut kelapa yaitu dengan menimbang berat serabut kelapa setelah digunakan sebagai filter dan dikurang berat serabut kelapa sebelum digunakan sebagai filter.

Tabel 2. Sisa Arang Setelah Pengujian Masing-masing Rangkaian

\begin{tabular}{|c|c|c|}
\hline no & rangkaian & $\begin{array}{c}\text { Sisa arang setelah } \\
\text { proses pengujian }(\mathrm{kg})\end{array}$ \\
\hline 1 & R1 & 2,0 \\
\hline 2 & R2 & 3,3 \\
\hline 3 & R3 & 3,2 \\
\hline 4 & R4 & 3,4 \\
\hline
\end{tabular}

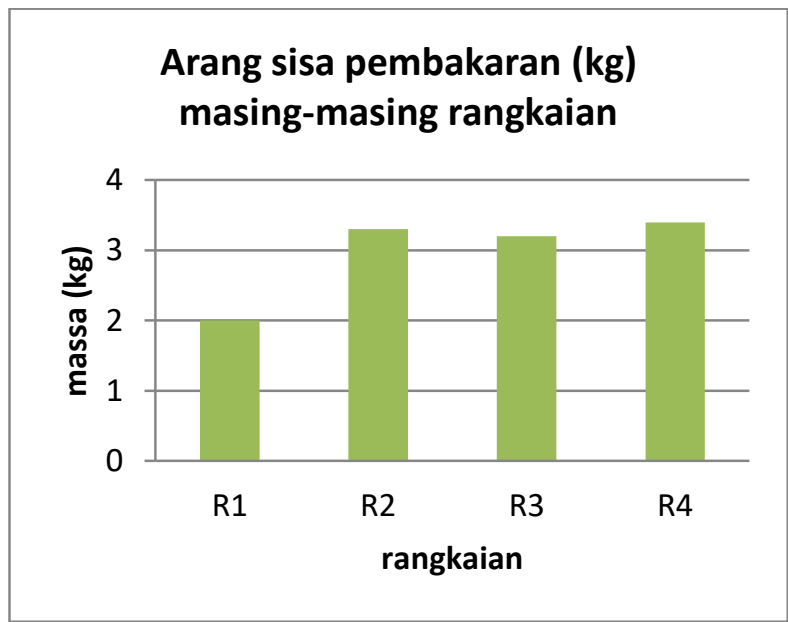

Gambar 8. Arang sisa pembakaran masingmasing rangkaian 
Tabel 3. Data banyak tar yang dapat dipisahkan oleh setiap rangkaian

\begin{tabular}{|c|c|c|c|}
\hline Rangkaian & $\begin{array}{c}\text { Siklon } \\
\text { (gram) }\end{array}$ & $\begin{array}{c}\text { Filter } \\
\text { (gram) }\end{array}$ & $\begin{array}{c}\text { Burner } \\
\text { (gram) }\end{array}$ \\
\hline R1 & - & - & 490 \\
\hline R2 & 320 & - & 100 \\
\hline R3 & - & 380 & 100 \\
\hline R4 & 320 & 100 & 70 \\
\hline
\end{tabular}

Berdasarkan dari pengujian banyaknya tar yang dipisahkan dari siklon, filter, dan burner seperti pada Tabel 3 terlihat $\mathrm{R}_{1}$ yang tidak menggunakan siklon dan filter sehingga tar dipisahkan hanya melalui pembuangan tar pada bagian bawah burner yang sudah diberi katup, tar yang dapat dipisahkan oleh rangkaian 1 sebanyak 490 gram.

Dan pada $\mathrm{R}_{2}$ menggunakan siklon dan tidak menggunakan filter, siklon pada $\mathrm{R}_{2}$ mampu memisahkan tar sebanyak 320 gram, dan tar yang dipisahkan oleh katup diburner sebanyak 100 gram, maka tar yang dapat dipisahkan rangkaian 2 sebanyak 420 gram.

Kemudian pada $\mathrm{R}_{3}$ menggunakan filter dengan media padatan serabut kelapa, berat serabut kelapa sebelum digunakan 70 gram, dan berat serabut kelapa setelah digunakan 380 gram, berat serabut kelapa setelah digunakan dikurangai berat serabut sebelum digunakan yaitu 310 gram dan ditambah banyak nya tar pada katup burner sebanyak 100 gram maka tar yang dapat dipisahkan oleh $\mathrm{R}_{3}$ sebanyak 410 gram, pada rangkaian 3 tar hanya melewati filter, sehingga pada gambar $\mathrm{R}_{3}$ serabut kelapa yang sudah digunakan terlihat berwarna sangat hitam mengharuskan penggantian serabut kelapa baru agar tidak mengurangi kinerja filter.

Dan pada $\mathrm{R}_{4}$ menggunakan siklon dan filter, telah didapat banyaknya tar yang dipisahkan oleh siklon sebanyak 320 gram, dan tar yang dipisahkan oleh filter sebanyak 100 gram yaitu berat serabut setelah digunakan dikurangi berat serabut sebelum digunakan 70 gram maka tar yang dipisahkan oleh filter sebanyak 30 gram, pada katup burner mampu memisahkan tar sebanyak 70 gram, tar yang dipisahkan oleh $\mathrm{R}_{4}$ sebnyak 420 gram, serabut kelapa $\mathrm{R}_{4}$ berwarna hitam agak kecokelatan karena tar yang dipisahkan oleh filter tidak terlalu banyak dibandingkan filter pada $\mathrm{R}_{3}$, hal ini disebabkan tar yang akan melewati filter terlebih dahulu melewati siklon dan terjadi pemurnian syn-gas pada siklon.

\section{Kesimpulan}

Dari hasil pengujian gasifikasi tipe updraft dengan penambahan cyclone dan filter ,dengan menggunakan biomasa kulit kelapa muda, dapat disimpulkan sebagai berikut :

1. Pengaruh penambahan cyclone dan filter terhadap hasil pembakaran (nyala api) sangat besar sekali, yaitu pada warna api orange kemerahan dan bersih dengan asap yang sedikit serta besar nya api yang keluar dari burner, dengan suhu api mencapai $375^{\circ} \mathrm{C}$. Dan jika dibandingkan dengan yang tidak menggunakan cyclone, dan filter nyala api berwarna merah dan masih bercampur asap, dengan api yang kecil, serta terjadi semburan tar dibagian burner, suhu api diburner mencapai $311^{\circ} \mathrm{C}$.

2. Pengaruh penambahan cyclone, dan filter terhadap Lama pembakaran syngas pada burner yaitu mencapai \pm 7 menit. Jika tidak menggunakan cyclone, dan filter lama pembakaran syn-gas diburner hanya mencapai \pm 2 menit.

3. Tar yang dapat dipisahkan oleh cyclone pada rangkaian R4 (reaktor, blower cyclone, filter dan burner) yaitu sebanyak 320 gram dan tar yang dapat dipisahkan oleh filter sebanyak 70 gram begitupun diburner dapat menampung tar sebanyak 70 gram. 


\section{Daftar Pustaka}

[1]. Arisanti, Yovita Reiny ,. Utami, Annisa Widyanti , 2009, Gasifikasi Limbah Kulit Biji Kopi Dalam Reaktor Fixed Bed Dengan Sistem Inverted Downdraft Gasifier : Distribusi Suhu, Simposium Nasional Rapi Viii 2009 Issn : 1412-9612.

[2]. Najib, Lailun,. Darsopuspito, Sudjud,. 2012, Karakterisasi Proses Gasifikasi Biomassa Tempurung Kelapa Sistem Downdraft Kontinyu dengan Variasi Perbandingan Udara-Bahan Bakar (AFR) dan Ukuran Biomassa, Jurnal Teknik ITS Vol. 1, No. 1, (Sept. 2012) Issn: 2301-9271.

[3]. Iskandar T. 2012. Pemanfaatan Limbah Pertanian Sebagai Alternatif Melalui Konversi Thermal. Jurusan Teknik Kimia Universitas Tribuwana Tunggadewi. Jawa Timur.

[4]. Iswanto T, Rifai M, Rahmawati Y dan Susiato. 2015. Desain Pabrik Synthetic Gas (Syngas) Dari Gasifikasi Batu Bara Kualitas Rendah Sebagai Pasokan Gas PT. Pupuk Sriwijaya. Jurusan Teknik Kimia Institut Teknologi Sepuluh November (ITS). Surabaya.

[5]. Hantoko, Dwi, Taniadi, Joko , dan Herri. 2015. Simulasi Termodinamika

Perengkahan Tar Pada Keluaran Fixed Bed Gasifier. Jurusan Teknik Kimia, FTI, UPN Veteran Yogyakarta.
[6]. Agustian, Candra A,. M Indra, Gandidi, dan Burhanudin H. 2013. Kajian Eksperimental Gas Cleaner Yang Dimodifikasi Untuk Mengekstrak Tar Dalam Producer Gas. Jurusan Teknik Mesin Universitas Lampung. Lampung. 